\title{
PERLINDUNGAN HUKUM TERHADAP KONSUMEN DALAM PELAYANAN AIR MINUM OLEH PERUSAHAAN DAERAH AIR MINUM GIRI TIRTA KABUPATEN GRESIK
}

\author{
Moch. Nasichin ${ }^{1}$, Nurul Hidayati ${ }^{2}$ \\ 1. Dosean Program Studi Ilmu Hukum, Fakultas Hukum, Universitas Gresik \\ 2. Mahasisw Program Studi Ilmu Hukum, Fakultas Hukum, Universitas Gresik
}

\begin{abstract}
ABSTRAK
Masyarakat Kabupaten Gresik selaku pelanggan air minum seringkali hak-haknya tidak terpenuhi oleh PDAM Giri Tirta Kabupaten Gresik, namun pelanggan tetap dituntut membayar tagihan air dan dikenai sanksi apabila terlambat membayar. Penelitian ini bertujuan mengetahui bentuk perlindungan hukum terhadap konsumen dalam pelayanan air minum PDAM Giri Tirta dan mekanisme penyelesaian sengketa terhadap kelalaian pelayanan PDAM Giri Tirta. Penelitian ini menggunakan metode penelitian hukum normatif dengan meneliti peraturan perundangan khususnya UUPK dan bahan pustaka lain terkait perlindungan konsumen air minum. Hasil penelitian menunjukkan bahwa belum ada bentuk perlindungan hukum terhadap pelanggan PDAM Giri Tirta yang mengacu pada UUPK. Penyelesaian sengketa konsumen selama ini dilakukan secara damai antara pelanggan dengan PDAM Giri Tirta. Namun apabila pelanggan belum merasa puas atas penyelesaian sengketa oleh PDAM Giri Tirta, pelanggan dapat menyelesaikan sengketanya melalui lembaga pengadilan atau badan penyelesaian sengketa konsumen (BPSK).
\end{abstract}

Kata Kunci: Air Minum, Konsumen, PDAM, UUPK.

\section{PENDAHULUAN}

\subsection{Latar Belakang}

Pertumbuhan sektor perdagangan yang semakin melaju dan pemasaran global berskala dunia membuat pelaku usaha berlomba menghasilkan barang dan jasa guna memenuhi kebutuhan konsumen yang semakin bervariasi seiring dengan perkembangan zaman dan teknologi. Sayangnya tidak semua pelaku usaha bersaing secara sehat. Konsumen dalam memenuhi kebutuhan terhadap produk yang dihasilkan produsen baik berupa barang dan atau jasa perlu untuk melindungi dirinya dari produk yang dikonsumsi. Dari sisi konsumen, menurut Az. Nasution, perlindungan yang diperlukan adalah agar produk itu memberikan manfaat bagi tubuh (keselamatan) dan atau jiwa (keamanannya), bukan malah menyebabkan ia sakit, meninggal dan atau dirugikan harta-bendanya. ${ }^{1}$

Salah satu upaya yang dilakukan Pemerintah untuk mewujudkan keseimbangan perlindungan kepentingan konsumen dan pelaku usaha serta menciptakan perekonomian yang sehat adalah dengan menerbitkan Undang-Undang Nomor 8 Tahun 1999 tentang Perlindungan Konsumen (UUPK). UndangUndang tersebut secara umum mengatur tentang hak dan kewajiban konsumen dan pelaku usaha, hal-hal yang dilarang dilakukan oleh pelaku usaha, tanggung jawab pelaku usaha, pengawasan perlindungan konsumen, serta upaya penyelesaian apabila

1 AZ. Nasution, Hukum Perlndungan Konsumen, Suatu Pengantar, Diadit Media, Jakarta, 2011, h. 23. 
terjadi sengketa antara konsumen dengan pelaku usaha.

Kebutuhan yang harus terpenuhi demi kelangsungan hidup di antaranya adalah kebutuhan terhadap air. Untuk memenuhi tanggung jawab negara dalam menjamin pemenuhan hak rakyat atas air minum, Pemerintah menyelenggarakan Sistem Penyediaan Air Minum (SPAM). Sebagaimana diatur dalam Pasal 36 ayat (1) PPSPAM bahwa penyelenggaraan SPAM menjadi tanggung jawab Pemerintah Pusat dan atau Pemerintah Daerah sesuai dengan kewenangannya guna memenuhi kehidupan yang sehat, bersih, dan produktif sesuai dengan ketentuan peraturan perundangundangan. Untuk penyelenggaran SPAM di daerah, Pemerintah menyerahkan penyelenggaraan SPAM kepada Badan Usaha Milik Daerah dalam hal ini Perusahaan Daerah Air Minum (PDAM).

Terciptanya hubungan hukum antara PDAM selaku produsen dan pelanggan PDAM selaku konsumen adalah adanya kewajiban PDAM untuk menyediakan air minum sesuai standar kesehatan yang berlaku dan dapat dinikmati selama 24 jam sehari. Pelanggan sebagai penerima jasa berkewajiban membayar tagihan air sesuai dengan tarif yang telah ditentukan berdasarkan pemakaian yang tertera pada meter air di rumah pelanggan. Dalam pelaksanaannya, seringkali hak-hak konsumen tidak terpenuhi.

PDAM Giri Tirta Kabupaten Gresik selaku penanggung jawab pengelolaan air minum bagi masyarakat di Kabupaten Gresik juga diliputi berbagai permasalahan yang sering dikeluhkan pelanggannya. Selain kualitas air minum yang tidak layak, permasalahan yang sering dikeluhkan oleh pelanggan adalah kontinuitas aliran air, kemacetan air hingga berhari-hari, air tidak lancar, pipa bocor, dan tagihan rekening air yang tidak sesuai dengan pemakaian pelanggan. Sementara pelayanan yang diberikan terkadang tidak diberikan penyelesaian oleh PDAM Giri Tirta, pelanggan tetap dituntut membayar tagihan air dan akan dikenai sanksi apabila terlambat melakukan pembayaran baik berupa denda, pemutusan sementara, bahkan pencabutan instalasi pelanggan.

Sesuai Pasal 4 huruf a UUPK bahwa konsumen berhak atas kenyamanan, keamanan, dan keselamatan dalam mengkonsumsi barang dan atau jasa. Dalam hal ini air minum yang layak konsumsi sesuai standar peraturan yang berlaku. Selain itu pelanggan juga berhak memperoleh ganti rugi apabila air minum yang diperoleh dari PDAM Giri Tirta tidak layak untuk dikonsumsi. Pelaku usaha wajib memberikan ganti rugi kepada konsumen, ketika ada konsumen yang merasa dirugikan akibat membeli, menggunakan, dan mengkonsumsi barang dan atau jasa yang diedarkan serta diperdagangkannya. ${ }^{2}$ Berdasarkan penjabaran di atas, maka dilakukan penelitian dengan judul "Perlindungan Hukum Terhadap Konsumen Dalam Pelayanan Air Minum Oleh Perusahaan Daerah Air Minum Giri Tirta Kabupaten Gresik"

Eli Wuria Dewi, Hukum Perlindungan Konsumen, Graha Ilmu, Yogyakarta, 2015, h. 67. 


\subsection{Perumusan Masalah}

Berdasarkan latar belakang yang telah diuraikan, dapat dirumuskan permasalahan dalam penelitian ini sebagai berikut:

1. Bagaimana bentuk perlindungan hukum terhadap konsumen dalam pelayanan air minum oleh PDAM Giri Tirta Kabupaten Gresik?

2. Bagaimana mekanisme penyelesaian sengketa konsumen terhadap kelalaian pelayanan yang dilakukan oleh PDAM Giri Tirta Kabupaten Gresik?

\section{TINJAUAN PUSTAKA}

\subsection{Pengertian Konsumen}

Undang-Undang Nomor 8 Tahun 1999 tentang Perlindungan Konsumen (UUPK) merupakan dasar hukum utama yang memberikan perlindungan hukum dan jaminan kepastian hukum terhadap hak-hak konsumen yang merasa dirugikan oleh pelaku usaha. ${ }^{3}$ Dengan adanya peraturan perundangundangan yang mengatur khusus mengenai perlindungan hukum terhadap konsumen, maka masyarakat dapat mengajukan tuntutan dan menempuh upaya hukum ketika mengalami kerugian yang disebabkan oleh pelaku usaha. Hal tersebut dikarenakan UUPK telah mengatur pula mengenai penyelesaian permasalahan konsumen dan upaya hukum apa yang dapat ditempuh dalam penyelesaian sengketa konsumen.

Disebutkan dalam Pasal 1 angka 2 UUPK, konsumen adalah setiap orang pemakai barang dan atau jasa yang tersedia dalam masyarakat, baik bagi kepentingan diri sendiri, keluarga, orang lain, maupun makhluk

\footnotetext{
${ }^{3}$ Ibid, h. 54
}

hidup lain dan tidak untuk diperdagangkan. Pengertian konsumen menurut UUPK ini mencakup pemakaian barang dan atau jasa selain untuk manusia. Hal ini berarti bahwa UUPK dapat memberikan perlindungan kepada konsumen yang bukan manusia (hewan, maupun tumbuh-tumbuhan). ${ }^{4}$

\subsection{Hak dan Kewajiban Konsumen}

UUPK telah mengatur hak konsumen dalam pasal 4. Hak konsumen yaitu:

a. hak atas kenyamanan, keamanan dan keselamatan dalam mengkonsurnsi barang dan atau jasa;

b. hak untuk memilih barang dan atau jasa serta mendapatkan barang dan atau jasa tersebut sesuai dengan nilai tukar dan kondisi serta jaminan yang dijanjikan;

c. hak atas informasi yang benar, jelas, dan jujur mengenai kondisi dan jaminan barang dan atau jasa;

d. hak untuk didengar pendapat dan keluhannya atas barang dan atau jasa yang digunakan;

e. hak untuk mendapatkan advokasi, perlindungan, dan upaya penyelesaian sengketa perlindungan konsumen secara patut;

f. hak untuk mendapat pembinaan dan pendidikan konsumen;

g. hak untuk diperlakukan atau dilayani secara benar dan jujur serta tidak diskriminatif;

h. hak untuk mendapatkan komnpensasi, ganti rugi dan atau penggantian, apabila barang dan atau jasa yang diterima tidak

4 Ahmadi Miru, Prinsip-Prinsip Perlindungan Konsumen, Raja Grafindo Persada, Jakarta, 2011, h. 21. 
sesuai dengan perjanjian atau tidak sebagaimana mestinya;

i. hak-hak yang diatur dalam ketentuan peraturan perundang-undangan lainnya.

Sedangkan kewajiban konsumen diuraikan dalam Pasal 5 UUPK berikut:

a. membaca atau mengikuti petunjuk informasi dan prosedur pemakaian atau pemanfaatan barang dan atau jasa, demi keamanan dan keselamatan;

b. beritikad baik dalam melakukan transaksi pembelian barang dan atau jasa;

c. membayar sesuai dengan nilai tukar yang disepakati;

d. mengikuti upaya penyelesaian hukum sengketa perlindungan konsumen secara patut.

\subsection{Perlindungan Konsumen}

Perlindungan hukum bagi konsumen merupakan sebuah perangkat hukum yang diciptakan oleh lembaga pemerintah untuk dapat memberikan perlindungan hukum dan jaminan kepastian hukum bagi para konsumen dari berbagai macam permasalahan ataupun sengketa konsumen karena merasa dirugikan oleh pelaku usaha. ${ }^{5}$

Dalam hal penyediaan akses air minum, selain melalui PDAM sebagai pengelola dan penyedia air minum, pemerintah telah menerbitkan regulasi untuk menjamin pemenuhan hak rakyat atas air minum dan akses terhadap air minum yaitu Peraturan Pemerintah Nomor 122 Tahun 2015 tentang Sistem Penyediaan Air Minum. Sistem Penyediaan Air Minum yang selanjutnya disingkat SPAM, sebagaimana didefinisikan dalam Pasal 1 Peraturan Pemerintah Nomor
122 Tahun 2015 tentang Sistem Penyediaan Air Minum (PPSPAM) merupakan satu kesatuan sarana dan prasarana penyediaan air minum. Penyelenggaraan SPAM merupakan serangkaian kegiatan dalam melaksanakan pengembangan dan pengelolaan sarana dan prasarana yang mengikuti proses dasar manajemen untuk penyediaan air minum kepada masyarakat.

Sejalan dengan UUPK, PPSPAM mengatur mengenai hak dan kewajiban konsumen, khususnya pelanggan air minum. Namun dalam PPSPAM tidak diuraikan secara khusus terkait perlindungan hukum pelanggan air minum seperti tanggung jawab penyelenggara SPAM kepada pelanggan air minum apabila pelanggan tidak memperoleh hak-haknya secara patut, atau pun tanggung jawab penyelenggara SPAM untuk memberikan ganti rugi atas kerusakan, pencemaran, dan atau kerugian pelanggan akibat mengkonsumsi barang dan atau jasa yang diperdagangkan sebagaimana yang diatur dalam Pasal 19 UUPK. Dalam Pasal 62 PPSPAM hanya menjelaskan bahwa apabila penyelenggara SPAM tidak mampu memenuhi kewajibannya untuk menyelenggarakan SPAM sesuai ketentuan yang ditetapkan, maka pemerintah dapat mengambil alih pengelolaan SPAM.

\subsection{METODE PENELITIAN}

\subsection{Tipe Penelitian}

Penelitian ini menggunakan metode penelitian hukum normatif. Penelitian hukum normatif atau penelitian hukum kepustakaan adalah penelitian hukum yang dilakukan

\footnotetext{
${ }^{5}$ Eli Wuria Dewi, Op. Cit, h. 4
} 
dengan meneliti bahan pustaka atau data sekunder belaka. ${ }^{6}$

\subsection{Sumber Bahan Hukum}

Penelitian ini menggunakan jenis data sekunder yang meliputi:

a) Bahan hukum primer

Bahan hukum primer yang digunakan terdiri dari peraturan perundang-undangan, catatan resmi, risalah dalam pembuatan perundang-undangan dan putusan hakim. ${ }^{7}$ Penelitian ini menggunakan sumber bahan hukum primer yaitu Undang-Undang Nomor 8 Tahun 1999 tentang Perlindungan Konsumen, Peraturan Pemerintah Nomor 122 Tahun 2015 tentang Sistem Penyediaan Air Minum, Peraturan Menteri Kesehatan Nomor 492/MENKES/PER/IV/2010 tentang

Persyaratan Kualitas Air Minum.

b) Bahan hukum sekunder

Bahan hukum sekunder yang utama adalah buku teks karena buku teks berisi mengenai prinsip-prinsip dasar ilmu hukum dan pandangan-pandangan klasik para sarjana yang mempunyai kualifikasi tinggi. ${ }^{8}$ Bahan hukum skunder yang digunakan yaitu jurnal dan artikel ilmiah.

c) Bahan hukum tersier

Bahan hukum tersier yakni bahan yang memberikan petunjuk maupun penjelasan terhadap bahan hukum primer dan sekunder, contohnya adalah kamus,

${ }^{6}$ Soerjono Soekanto dan Sri Mamudji, Penelitian Hukum Normatif, Suatu Tinjauan Singkat, Raja Grafindo Persada, Jakarta, 2015, h. 13.

7 Peter Mahmud Marzuki, Penelitian Hukum, Kencana Prenada Media Group, Jakarta, 2016, h. 181.

${ }^{8}$ Ibid, h. 182. ensiklopedia, indeks kumulatif, dan seterusnya. $^{9}$ Dalam penelitian ini menggunakan bahan hukum tersier berupa kamus hukum, kamus besar bahasa Indonesia, dan lain-lain sebagai penunjang.

\subsection{Analisis Bahan Hukum}

Penelitian ini menggunakan teknik penelitian deskriptif. Setelah semua data yang dibutuhkan terkumpul, langkah selanjutnya menginventarisasi data yang diperoleh. Hasil inventarisasi data diuraikan dalam bentuk kalimat yang baik dan benar, dianalisis, dan diinterpretasikan dengan peraturan perundangundangan yang berlaku terkait dengan penyediaan air minum, pemenuhan hak-hak konsumen, dan tanggung jawab PDAM Giri Tirta Kabupaten Gresik selaku pelaku usaha sesuai UUPK.

\section{HASIL PENELITIAN DAN} PEMBAHASAN

\section{A. Bentuk Perlindungan Hukum Terhadap Konsumen Dalam \\ Pelayanan Air Minum Oleh PDAM Giri Tirta Kabupaten Gresik}

Bagi masyarakat dan industri di Kabupaten Gresik, Jawa Timur, tugas pengelolaan air bersih diserahkan oleh Pemerintah Kabupaten Gresik kepada PDAM Giri Tirta Kabupaten Gresik. Badan Usaha Milik Daerah tersebut bertanggung jawab terhadap penyediaan air minum bagi masyarakat dan industri di Kabupaten Gresik sesuai dengan standar kesehatan yang diatur dalam Peraturan Menteri Kesehatan Nomor 492/MENKES/PER/IV/2010 tentang

Persyaratan Kualitas Air Minum. Loc. Cit.

${ }^{9}$ Soerjono Soekanto dan Sri Mamudji, 
Jumlah pelanggan PDAM Giri Tirta tahun 2017 sebanyak 91.516 unit pelanggan, yang terbagi atas 85.889 unit adalah pelanggan domestik (rumah tangga) dan 5.627 unit adalah pelanggan non domestik. ${ }^{10}$

Standar mutu yang berlaku untuk penyediaan air minum adalah air minum yang sesuai standar kesehatan yang ditetapkan dalam Peraturan Menteri Kesehatan Republik Indonesia No. 492/MENKES/PER/IV/2010 tentang Persyaratan Kualitas Air Minum. Air minum yang disediakan oleh PDAM Giri Tirta meskipun kualitasnya telah diuji secara berkala pada laboratorium internal dan eksternal, pada kenyataannya pelanggan mengadukan air minum yang tidak layak seperti air keruh dan mengandung lumut. Hal ini dapat disebabkan karena tercemar oleh kotoran dalam pipa sehingga saat air minum sampai kepada pelanggan menjadi air minum yang tidak layak konsumsi.

Kontinuitas pengaliran air minum kepada pelanggan juga menjadi permasalahan pelanggan. Idealnya, pelanggan tentu menginginkan dapat menikmati air minum selama 24 jam sehari dengan aliran air yang tidak kecil dan tanpa macet. Permasalahan aliran air tidak 24 jam terjadi terlebih lagi apabila wilayah pelayanan berada di lokasi yang tinggi, sehingga pasti akan sulit mengalirkan air selama 24 jam di lokasi tersebut. ${ }^{11}$

${ }^{10}$ Perusahaan Daerah Air Minum Giri Tirta Kabupaten Gresik, Laporan Tahunan 2017, h. 9

${ }^{11}$ Gigih Yuli Asmara, Pengaliran Air 24 Jam di Wilayah Elevasi Tinggi dengan Sistem Otomasi Distribusi Air, Aplikasi di PDAM Kota Malang, Majalah Air Minum Edisi 269 Februari 2018, h. 34
Jenis kelalaian lain terkait gangguan aliran air PDAM Giri Tirta adalah kebocoran pipa. Jaringan pipa yang berkarat dan belum diadakan penggantian menjadi penyebab utama kebocoran. Karena itu diperlukan revitaliasi jaringan pipa yang berusia tua. Kebocoran pada pipa harus segera mendapat penanganan agar tidak sampai mengganggu kelancaran pendistribusian air kepada pelanggan dan menyebabkan tingkat kehilangan air menjadi tinggi.

Permasalahan lain adalah pelanggan sering mengeluhkan tagihan air yang tidak sesuai pemakaian sebenarnya. Hal ini dapat disebabkan karena kelalaian pencatat meter dalam mencatat angka meter air pelanggan, pagar rumah pelanggan terkunci dan tidak terdapat papan informasi angka meter air sehingga menyulitkan petugas untuk menetapkan pemakaian air pelanggan, meter air buram dan tidak akurasi, dan sebab lainnya yang membuat pemakaian air pelanggan ditetapkan berdasarkan rata-rata pemakaian air. Untuk itu PDAM Giri Tirta telah melakukan inovasi melalui pembacaan meter dengan mengambil gambar angka meter air pelanggan menggunakan android sehingga pemakaian air pelanggan dapat diketahui secara pasti. ${ }^{12}$

Sejumlah kelalaian penyediaan air minum oleh PDAM Giri Tirta kepada pelanggan dipengaruhi beberapa faktor. Tantangan terbesar yang dihadapi oleh PDAM sebagai pengelola dan penyedia air minum bagi masyarakat adalah pencarian sumber

12 Perusahaan Daerah Air Minum Giri Tirta Kabupaten Gresik, Op. Cit, h. 29 
air. ${ }^{13}$ Keberpihakan pemerintah di sektor sumber daya air juga masih kurang. Ini bisa dilihat dari persen dari alokasi anggaran yang hanya 0,02 persen dari produk domestik bruto dan kurang dari satu persen dari APBN. ${ }^{14}$ Komitmen pemerintah daerah untuk menggelontorkan dana investasi masih sangat lemah sehingga PDAM sulit meningkatkan cakupan pelayanan. ${ }^{15}$

Faktor lain yang menyebabkan hak-hak konsumen tidak terpenuhi adalah dari sisi regulasi. Di sana sini ada peraturan perundang-undangan yang tumpang tindih. Sampai sekarang masih banyak PDAM yang tarifnya berada di bawah keekonomian, namun PDAM tidak mungkin menaikkan tarif air minum sesuai keekonomian karena intervensi kepala daerah yang masih kuat terhadap PDAM. ${ }^{16}$

Penyelenggaraan pelayanan publik mendasar di Indonesia seperti air, kesehatan, pendidikan, dan transportasi, dari sisi kualitas produk layanan publik ternyata tak layak untuk digunakan masyarakat, walaupun akhirnya masyarakat tetap menggunakan produk tersebut dikarenakan ketiadaan alternatif layanan publik yang lainnya. ${ }^{17}$

Dalam pelayanan air minum yang diselenggarakan oleh PDAM Giri Tirta,

${ }^{13}$ Muhammad Zainal Fattah, Harapan Baru Para Tukang Ledeng, Majalah Air Minum Edisi 268 Januari 2018, h. 10

${ }^{14}$ Muhammad Reza Sahib, DPR Masih Membuka Masukan Untuk RUU SDA, Majalah Air Minum Edisi 268 Januari 2018, h. 27

15 Victor Sihite, Tugas Berat Memenuhi

Hak Rakyat Atas Air, Majalah Air Minum Edisi 268 Januari 2018, h. 49

16 Ibid

17 Siti Rochmah, Kebijakan Pelayanan Studi Pada Kebijakan Pelayanan Air Bersih, UB Press, Malang, 2013, h. 38 hubungan dengan pelanggan diatur dalam Peraturan Direksi Perusahaan Daerah Air Minum Kabupaten Gresik Nomor 1 Tahun 2010 tentang Ketentuan-Ketentuan Pokok Bagi Pelanggan Perusahaan Daerah Air Minum Kabupaten Gresik (PERDIR 1/2010). Peraturan Direksi dimaksud ditetapkan untuk meningkatkan tertib administrasi pelanggan PDAM Giri Tirta.

Kompensasi untuk pelanggan tidak tertuang dalam PERDIR 1/2010. Pelanggan yang tidak memenuhi kewajiban membayar rekening air dan non air akan dikenai sanksi oleh PDAM Giri Tirta. Namun bagi PDAM Giri Tirta, apabila tidak dapat mendistribusikan air kepada pelanggan secara kontinu sesuai standar kesehatan yang berlaku, tidak ada kompensasi kerugian yang diberikan oleh PDAM Giri Tirta kepada pelanggan. Belum ada bentuk perlindungan hukum terhadap pelanggan PDAM Giri Tirta yang mengacu pada Undang-Undang Nomor 8 Tahun 1999 tentang Perlindungan Konsumen. Kompensasi yang diberikan kepada pelanggan hanya untuk perbaikan meter air pelanggan yang mengalami kerusakan. Itu pun tidak semua perbaikan meter air ditanggung biayanya oleh PDAM Giri Tirta. Ketentuan perbaikan meter air pelanggan diatur dalam Pasal 4 angka (7) PERDIR 1/2010.

\section{B. Mekanisme Penyelesaian Sengketa \\ Konsumen Terhadap Kelalaian \\ Pelayanan Yang Dilakukan Oleh Pdam Giri Tirta Kabupaten Gresik}

Penyelesaian sengketa konsumen sebagaimana diatur dalam Pasal 45 UUPK dapat ditempuh melalui pengadilan atau di 
luar pengadilan berdasarkan pilihan sukarela para pihak yang bersengketa, yaitu:

1. Penyelesaian sengketa di luar pengadilan

a. Penyelesaian secara damai para pihak sendiri

b. Penyelesaian sengketa melalui lembaga yang berwenang, yaitu BPSK dengan menggunakan mekanisme konsiliasi, mediasi, atau arbitrase.

2. Penyelesaian sengketa konsumen melalui pengadilan yang berada di lingkungan peradilan umum

Dalam penjelasan Pasal 45 ayat (2)

UUPK, penyelesaian sengketa konsumen tidak menutup kemungkinan dilakukan secara damai oleh para pihak yang bersengketa, yaitu pelaku usaha dan konsumen tanpa melalui pengadilan atau badan penyelesaian sengketa konsumen, dan sepanjang tidak bertentangan dengan UUPK. Pada setiap tahap diusahakan untuk menggunakan penyelesaian damai oleh kedua belah pihak yang bersengketa. UUPK menghendaki penyelesaian secara damai, merupakan upaya hukum yang justru terlebih dahulu harus ditempuh oleh para pihak yang bersengketa, sebelum memilih menyelesaikan sengketa melalui lembaga pengadilan atau badan penyelesaian sengketa konsumen (BPSK). ${ }^{18}$

Salah satu bentuk penyelesaian sengketa konsumen secara damai dapat dilakukan dengan pemberian ganti rugi seketika. Hal itu sesuai dengan Pasal 19 UUPK yakni pelaku usaha bertanggung jawab

18 Susanti Adi Nugroho, Proses Penyelesaian Sengketa Konsumen Ditinjau dari Hukum Acara dan Implementasinya, Kencana Prenada Media Grup, Jakarta, 2008, h. 99 memberikan ganti rugi atas kerusakan, pencemaran, dan atau kerugian konsumen akibat mengkonsumsi barang dan atau jasa yang dihasilkan atau diperdagangkan. Ganti rugi sebagaimana dimaksud dapat berupa pengembalian uang atau penggantian barang dan atau jasa yang sejenis atau setara nilainya, atau perawatan kesehatan dan atau pemberian santunan yang sesuai dengan ketentuan peraturan perundang-undangan yang berlaku.

Sebagai pelaku usaha, PDAM wajib bertanggung jawab terhadap kerugian yang dialami oleh pelanggan sebagaimana yang telah dilakukan oleh PDAM Giri Tirta kepada pelanggannya. Untuk meter air yang mengalami kerusakan, pelanggan mendapatkan penggantian meter air apabila berdasarkan hasil tera meter menunjukkan meter air memang dalam kondisi rusak. Dalam hal keberatan pelanggan atas tagihan rekening air minum, PDAM Giri Tirta memberikan keringanan kepada pelanggan untuk melakukan pembayaran tagihan rekening air minum dengan cara mengangsur. Hal ini diatur dalam Pasal 10 PERDIR 1/2010.

Sedangkan untuk penyelesaian masalah pendistribusian air pelanggan, PDAM Giri Tirta menindaklanjuti dengan peninjauan pendistribusian air di wilayah yang diadukan oleh pelanggan atau pengecekan petugas secara langsung ke lokasi pelanggan untuk melihat apakah terdapat pipa pelanggan yang tersumbat atau bocor. PDAM Giri Tirta tidak memberikan kompensasi ganti rugi kepada pelanggan selama pelanggan tidak menerima aliran air minum dari PDAM Giri Tirta. Pemberian ganti rugi oleh PDAM Giri Tirta dilakukan dengan melakukan perbaikan terhadap kerusakan jaringan perpipaan yang 
dikelola oleh PDAM Giri Tirta yang telah mengakibatkan kerugian bagi pihak konsumen atau pelanggan.

Penyelesaian pengaduan konsumen di PDAM Giri Tirta selama ini dilakukan secara damai antara pelanggan dengan PDAM Giri Tirta. Namun pelanggan juga dapat menyelesaikan sengketanya melalui lembaga pengadilan atau badan penyelesaian sengketa konsumen (BPSK) apabila pelanggan belum merasa puas atas penyelesaian sengketa yang dilakukan oleh pelaku usaha. Dengan adanya BPSK, maka penyelesaian sengketa konsumen dapat dilakukan secara cepat, mudah, dan murah. Cepat karena undang-undang menentukan dalam tenggang waktu 21 hari kerja, BPSK wajib memberikan putusannya sebagaimana disebutkan dalam Pasal 55 UUPK. Mudah karena prosedur administratif dan proses pengambilan putusan yang sangat sederhana. $^{19}$ Murah terletak pada biaya perkara yang terjangkau.

Tata cara penyelesaian sengketa konsumen oleh BPSK diatur dalam UU Nomor 8 Tahun 1999 tentang Perlindungan Konsumen jo. Keputusan Menteri Perindustrian dan Perdagangan Nomor 350/MPP/12/2001 tentang Pelaksanaan Tugas dan Wewenang Badan Penyelesaian Sengketa Konsumen. Proses penyelesaiannya pun diatur sangat sederhana dan sejauh mungkin dihindari suasana yang formal.

UUPK menentukan apabila telah dipilih upaya penyelesaian sengketa konsumen

19 Yusuf Shofie dan Somi Awan, Sosok Peradilan Konsumen Mengungkap Berbagai Persoalan Mendasar BPSK, Piramedia Jakarta, 2004, h. 17 dalam Susanti Adi Nugroho, Op. Cit, h.99 di luar pengadilan, gugatan melalui pengadilan hanya dapat ditempuh apabila upaya tersebut dinyatakan tidak berhasil oleh salah satu pihak atau oleh para pihak yang bersengketa.

\section{PENUTUP}

\section{A. Kesimpulan}

1. Dalam penyelenggaraan pelayanan air minum oleh PDAM Giri Tirta Kabupaten Gresik, ketentuan bagi pelanggan PDAM Giri Tirta diatur dalam Peraturan Direksi Nomor 1 Tahun 2010 tentang KetentuanKetentuan Pokok Bagi Pelanggan Perusahaan Daerah Air Minum Kabupaten Gresik. Namun peraturan tersebut hanya mengatur tertib administrasi bagi pelanggan. Secara khusus belum ada bentuk perlindungan hukum terhadap pelanggan PDAM Giri Tirta yang mengacu pada UndangUndang Nomor 8 Tahun 1999 tentang Perlindungan Konsumen.

2. Penyelesaian sengketa konsumen terkait kelalaian pelayanan air minum oleh PDAM Giri Tirta Kabupaten Gresik selama ini dilakukan secara damai antara pelanggan dengan PDAM Giri Tirta. Namun apabila pelanggan belum merasa puas atas penyelesaian sengketa yang dilakukan oleh PDAM Giri Tirta, pelanggan dapat menyelesaikan sengketanya melalui lembaga pengadilan atau badan penyelesaian sengketa konsumen (BPSK).

\section{B. Saran}

1. Pemerintah diharapkan memberikan anggaran publik yang lebih besar dalam rangka pengembangan sistem penyediaan air minum agar program 100 persen 
akses aman air minum di tahun 2019 dapat tercapai.

2. Pemerintah Daerah agar mendukung pemulihan tarif bagi PDAM yang kurang sehat supaya berkinerja sehat sehingga akan berdampak pada optimalnya penyediaan air minum bagi masyarakat.

3. PDAM Giri Tirta Kabupaten Gresik diharapkan memberikan perlindungan hukum bagi pelanggannya dengan membuat regulasi khusus yang mengacu pada Undang-Undang Nomor 8 Tahun 1999 tentang Perlindungan Konsumen.

4. Pelanggan air minum apabila merasa dirugikan oleh pelayanan PDAM Giri Tirta Kabupaten Gresik dapat memperjuangkan haknya dengan melakukan upaya-upaya untuk mendapatkan hak tersebut dengan tetap mengupayakan penyelesaian sengketa secara damai terlebih dahulu. Namun pelanggan diharapkan tidak hanya mampu menuntut hak-haknya, tetapi juga harus memperhatikan kewajibannya.

\section{DAFTAR PUSTAKA}

Asmara, Gigih Yuli, Pengaliran Air 24 Jam di Wilayah Elevasi Tinggi dengan Sistem Otomasi Distribusi Air, Aplikasi di PDAM Kota Malang, Majalah Air Minum Edisi 269 Februari 2018.

Dewi, Eli Wuria, Hukum Perlindungan Konsumen, Graha Ilmu, Yogyakarta, 2015.

Fattah, Muhammad Zainal, Harapan Baru Para Tukang Ledeng, Majalah Air Minum Edisi 268 Januari 2018.

Marzuki, Peter Mahmud, Penelitian Hukum, Kencana Prenada Media Group, Jakarta, 2016.
Miru, Ahmadi, Prinsip-Prinsip Perlindungan Konsumen, Raja Grafindo Persada, Jakarta, 2011

Nasution, AZ, Hukum Perlndungan Konsumen, Suatu Pengantar, Diadit Media, Jakarta, 2011.

Nugroho, Susanti Adi, Proses Penyelesaian Sengketa Konsumen Ditinjau dari Hukum Acara dan Implementasinya, Kencana Prenada Media Grup, Jakarta, 2008.

Perusahaan Daerah Air Minum Giri Tirta Kabupaten Gresik, Laporan Tahunan Perusahaan Daerah Air Minum Giri Tirta Kabupaten Gresik 2017.

Peraturan Direksi PDAM Giri Tirta Kabupaten Gresik Nomor 1 Tahun 2010 tentang Ketentuan-Ketentuan Pokok Bagi Pelanggan/Konsumen Perusahaan Daerah Air Minum Kabupaten Gresik.

Republik Indonesia, Peraturan Menteri Kesehatan Nomor 492/MENKES/PER/IV/2010 tentang Persyaratan Kualitas Air Minum.

Republik Indonesia, Peraturan Pemerintah Nomor 122 Tahun 2015 tentang Sistem Penyediaan Air Minum.

Republik Indonesia, Undang-Undang Nomor 8 Tahun 1999 tentang Perlindungan Konsumen.

Rochmah, Siti, Kebijakan Pelayanan Studi Pada Kebijakan Pelayanan Air Bersih, UB Press, Malang, 2013.

Sahib, Muhammad Reza, DPR Masih Membuka Masukan Untuk RUU SDA, Majalah Air Minum Edisi 268 Januari 2018.

Shofie, Yusuf dan Somi Awan, Sosok Peradilan Konsumen Mengungkap Berbagai Persoalan Mendasar BPSK, Piramedia Jakarta, 2004.

Sihite, Victor, Tugas Berat Memenuhi Hak Rakyat Atas Air, Majalah Air Minum Edisi 268 Januari 2018.

Soekanto, Soerjono dan Sri Mamudji, Penelitian Hukum Normatif, Suatu Tinjauan Singkat, PT. Raja Grafindo Persada, Jakarta, 2015 